\title{
Exploring the Model of Abusive Supervision and Employee's Turnover Intention: Is Neuroticism a Moderator?
}

\author{
Edi Cahyono $^{1}$ and Syahriar Abdullah ${ }^{2}$ \\ \{edicahyono73@yahoo.co.id ${ }^{1}$, solocitywalker@gmail.com ${ }^{2}$ \} \\ Department of Management, STIE Atma Bhakti, Surakarta, Indonesia ${ }^{1}$ \\ Department of Accounting, Universitas Tunas Pembangunan, Surakarta, Indonesia ${ }^{2}$
}

\begin{abstract}
The purpose of this paper is twofold. First is to examine the relationship between employee's perception of abusive supervision and their turnover intention. Second is to investigate the moderating role of neuroticism on this relationship. The data was collected from 500 employees working at Rural Bank (BPR) in Surakarta, Indonesia through self-report questionnaires. The finding of the study confirms that abusive supervision is positively related to subordinates' turnover intention. The study also reveals that neuroticism moderated the relationship between abusive supervision and turnover intention.
\end{abstract}

Keywords: Abusive Supervision, Turnover Intention, Neuroticism.

\section{Introduction}

In the last decade, abusive supervision becomes a meaningful topic to observe. Researchers have not yet deeply put an interest on such a matter, yet abusive supervision is not something foreign for employees in Indonesia. Indonesia is a country of high power distance Hofstede (1983), where people at the higher place in the hierarchical structure posses an absolute power and control over their direct orders [1]. Thus, abusive conducts are prone to happen. In his study, Hancock (2000) found that abusive supervision is commonly experienced by employees in Indonesia [2].

Furthermore, past researches also indicate that abusive supervision may lead to negative impact to employees in a companies, among others low job satisfaction, poor organizational commitment, and degradation of organizational citizenship behavior [3]-[11]. Abusive supervision may also inflate company expense due to high turnover [12]-[15].

This research focuses on the relationship between abusive supervision and turnover intention with two underlying reasons. First, previous studies indicate that such a relationship is inconclusive. Abusive supervision may indeed incline towards high turnover intention [7], [13], [14], [16]. However, other researches come with an opposite finding [17]. These contrasting views open up an opportunity for researchers to clarify the connection between the two. Second, the limitation of reference on the correlation within the scope of companies in Indonesia provides a room for academics to contribute to the development of knowledge on this specific subject matter. 
This study serves two primary purposes. First, it explains the relationship between abusive supervision and employee's turnover intention. It is based on the social exchange theory which suggests that individuals receiving abusive supervision will then respond with high turnover intention [18], [19].

Second, this study proposes an alternative model by conceptualizing neuroticism as a variable that is expected to put a brighter spot on the relationship between abusive supervision and turnover intention. Several earlier researches took into account a moderating variable, yet only a very few bring about this personality trait as a moderator in highlighting the relationship. This idea is founded on the personality theory explaining that individuals scoring low in neuroticism tend to be more resistant to stress at workplace. They are more likely to be calm in dealing with problems, confident, and highly persistent when facing stressors [20][22]. Their intention in turnover is thus low when receiving abusive supervision, and vice versa [20], [23], [24].

\section{Method}

\subsection{Sample and Procedure}

The respondents consist of 500 employees of rural banks in Surakarta. Purposive sampling method was applied in selecting the respondents. The method is preferred in order to gain information parallel to the research of the study. The criteria of sample are categorized as follows: 1. Supervised at work, 2. A permanent employee, 3. Employed for at least 1 year. The data was gathered by means of hand-delivered questionnaires. Rewards were provided to encourage the participation of the respondents.

\subsection{Measurement of Variables}

Abusive supervision is an independent variable, measured by using 5 indicators adopted from Tepper (2000) and Mitchell \& Ambrose (2007) [25], [26].

Turnover intention functions as a dependent variable, measured through 4 items adopted from Alagaraja \& Shuck (2015) [27].

Neuroticism is a moderating variable, measured utilizing 5 indicators adopted from Goldberg (1990) and Haryanto et al., (2019) [28], [29].

All these variables were measured using a 5-point likert scale (1=strongly disagree, $5=$ strongly agree).

\section{Results}

Table 1 displays the description of respondents' profile. Respondents aged 22-30 years old is $30 \%, 31-40$ years old $61.5 \%, 41-50$ years old $5.7 \%$, and above 50 years old $2.8 \%$. $34 \%$ are males and $66 \%$ are females. $22 \%$ are high school/vocational school graduates, $14 \%$ hold an associate's degree, and 64\% hold a bachelor's degree. $73 \%$ are married and the remaining $27 \%$ are unmarried. 
Table 1. Profile of Respondents.

\begin{tabular}{lc}
\hline \multicolumn{1}{c}{ Variables } & $\begin{array}{c}\text { Percentage }(\%) \\
\mathrm{N}=500\end{array}$ \\
\hline Age (Year) & \\
$>50$ & 2.8 \\
$41-50$ & 5.7 \\
$31-40$ & 61.5 \\
$22-30$ & 30 \\
Sex & \\
Male & 34 \\
Female & 66 \\
Education Level & \\
Bachelor's degree & 64 \\
Associate's degree & 14 \\
High School/Vocational & School \\
Graduates & 22 \\
Marital Status & \\
Married & \\
Unmarried & 73 \\
\hline Sourc: Processed Primary Data, 2020 & 27 \\
\hline
\end{tabular}

Source: Processed Primary Data, 2020

Correlation test was conducted to identify inter-variables relationship. There is a positive and significant correlation between abusive supervision and turnover intention $(r=.603 ; p=<$ $0.01)$. Similar correlation is found between neuroticism and turnover intention $(\mathrm{r}=.387$; $\mathrm{p}=<0.01$ ).

Regression analysis was employed to test the formulated hypothesis. From the first hypothesis, abusive supervision correlates positive and significant with turnover intention $(B=2.802 ; \mathrm{p}<0.05)$ (See table 2). Statistically, hypothesis 1 is supported. Subsequently, a series of test using hierarchical regression analysis was carried out to comprehend the potential of neuroticism as a moderating variable in the correlation between abusive supervision and turnover intention. There were three steps of the analysis. First step was introducing neuroticism variable. Second was incorporating abusive supervision variable. Third was inserting interaction variable (multiplication of neuroticism and abusive supervision scores). As shown in Table 2, the regression test on the interaction effect of neuroticism and abusive supervision results in negative and significant $(B=-.021 ; \mathrm{p}<0.05)$. Therefore, neuroticism is statistically valid as a moderating variable between abusive supervision and turnover intention. Alternatively said, neuroticism may moderate the influence of abusive supervision towards turnover intention. Such an influence grows weaker in individuals of low neuroticism compared to those of high one. 
Table 2. Regression findings to understand the moderating effect of abusive supervision and neuroticism on Turnover Intention.

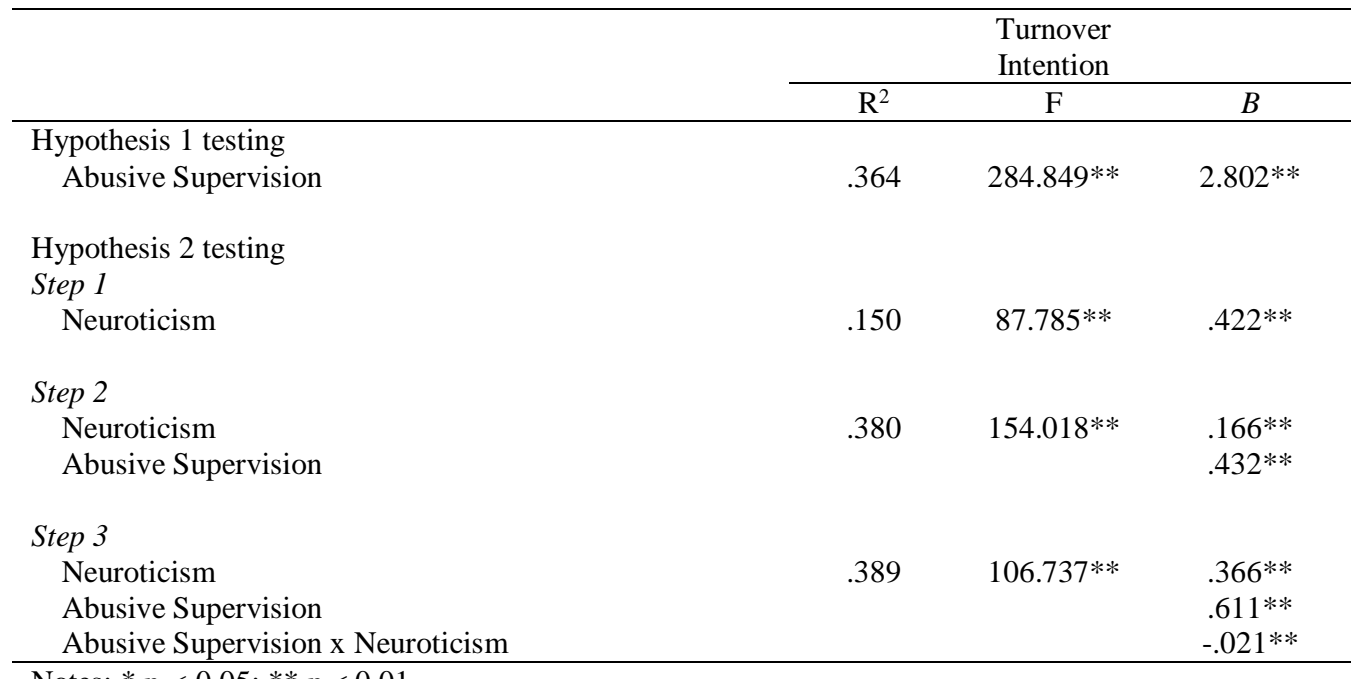

Notes: $* p<0.05 ; * * p<0.01$

Source: Author's Calculations, 2020

\section{Discussion}

This study serves two primary purposes. First is to examine the relationship between employee's perception of abusive supervision and their turnover intention. Second is to investigate the role of neuroticism as a moderating variable on this relationship. The first hypothesis appears to be supported, indicating positive and significant correlation between abusive supervision and turnover intention. This represents the fact that employees receiving abusive supervision tend to have higher turnover intention, and vice versa. This aligns with social exchange theory where poor treatment will be reciprocated the same, representing high turnover intention due to abusive supervision.

The second hypothesis is also supported by the test result, where neuroticism may moderate abusive supervision on turnover intention. This finding indicates that when receiving abusive supervision, people with different level of neuroticism leads to various degree of turnover intention. It confirms the personality theory suggesting that individuals will respond in a different behavior depending on the dimension of personality when facing stressors and negative conduct.

Employees scoring low in neuroticism will tend to withstand and tolerate abusive supervision thus they won't be affected in working, rendering them to have less intention to leave the job. On the contrary, employees with high level of neuroticism will regard abusive supervision an uncomfortable situation and stressor at work place, triggering them to leave the company. 


\section{Conclusion}

This study highlights the positive and significant correlation between abusive supervision and employee's turnover intention. Social exchange theory serves as a basis to clarify such an interaction. It is also revealed that neuroticism moderates the influence of abusive supervision on turnover intention, with personality as the underlying foundation. Conclusively, employees' response in dealing with abusive supervision varies depending on their level of neuroticism.

Acknowledgements. This research was conducted with the financial support of Direktorat Riset dan Pengabdian Masyarakat, Deputi Bidang Penguatan Riset dan Teknologi/Badan Riset dan Inovasi Nasional.

\section{References}

[1] Hofstede, G.: "National cultures in four dimensions: A research-based theory of cultural differences among nations," Int. Stud. Manag. Organ., vol. 13, no. 1-2, pp. 46-74, (1983).

[2] Hancock, P.: "The lived experience of female factory workers in rural West Java," Labor Manag. Dev. J., vol. 1, no. 1, pp. 1-18, (2000).

[3] Tepper, B. J.: "Abusive supervision in work organizations: Review, synthesis, and research agenda," J. Manage., vol. 33, no. 3, pp. 261-289, (2007).

[4] Martinko, M. J.Harvey, P.Brees, J. R.and Mackey, J.: "A review of abusive supervision research," J. Organ. Behav., vol. 34, no. S1, pp. S120-S137, (2013).

[5] Khan, S.: "Abusive supervision and negative employee outcomes: The moderating effects of intimidation and recognition," J. Gen. Manag., vol. 41, no. 1, pp. 61-81, (2015).

[6] Haryanto, B. and Cahyono, E.: "Relationship Between Abusive Supervision and Performance: The Role of Gender," Eur. Res. Stud. J., vol. 22, no. 3, pp. 305-311, (2019).

[7] Cahyono, E.Haryono, T.Haryanto, B.and Harsono, M.: "A New Insight in Relation between Abusive Supervision and Work Outcomes: A Conceptual Review.," Qual. to Success, vol. 21, no. $177,(2020)$.

[8] Cahyono, E.Haryono, T.Haryanto, B.and Harsono, M.: "The role of gender in the relationship between abusive supervision and employee's organisational citizenship behaviour in Indonesia," Int. J. Trade Glob. Mark., vol. 13, no. 3, pp. 311-322, (2020).

[9] Jiang, W.Wang, L.and Lin, H.: "The role of cognitive processes and individual differences in the relationship between abusive supervision and employee career satisfaction," Pers. Individ. Dif., vol. 99, pp. 155-160, (2016).

[10] Yu, K. et al.: "The role of affective commitment and future work self salience in the abusive supervision-job performance relationship," J. Occup. Organ. Psychol., vol. 89, no. 1, pp. 2845, (2016).

[11] Zellars, K. L.Tepper, B. J.and Duffy, M. K.: “Abusive supervision and subordinates' organizational citizenship behavior.," J. Appl. Psychol., vol. 87, no. 6, p. 1068, (2002).

[12] Tepper, B. J.Duffy, M. K.Henle, C. A.and Lambert, L. S.: "Procedural injustice, victim precipitation, and abusive supervision," Pers. Psychol., vol. 59, no. 1, pp. 101-123, (2006).

[13] Tepper, B. J.Carr, J. C.Breaux, D. M.Geider, S.Hu, C.and Hua, W.: "Abusive supervision, intentions to quit, and employees' workplace deviance: A power/dependence analysis," Organ. Behav. Hum. Decis. Process., vol. 109, no. 2, pp. 156-167, (2009).

[14] Rodwell, J.Brunetto, Y.Demir, D.Shacklock, K.and Farr- Wharton, R.: "Abusive supervision and links to nurse intentions to quit," J. Nurs. Scholarsh., vol. 46, no. 5, pp. 357-365, (2014).

[15] Pradhan, S.Jena, L. K.and Mohapatra, M.: "Role of gender on the relationship between abusive supervision and employee's intention to quit in Indian electricity distribution companies," Gend. Manag. An Int. J., vol. 33, no. 4, (2018).

[16] Hogh, A.Hoel, H.and Carneiro, I. G.: "Bullying and employee turnover among healthcare 
workers: a three- wave prospective study," J. Nurs. Manag., vol. 19, no. 6, pp. 742-751, (2011).

[17] Mathieu, C. and Babiak, P.: "Corporate psychopathy and abusive supervision: Their influence on employees' job satisfaction and turnover intentions," Pers. Individ. Dif., vol. 91, pp. 102 106, (2016).

[18] Blau, P. M.Exchange and power in social life. New Brunswick. New York: NJ: Transaction Publishers, 1964(1964).

[19] Cropanzano, R. and Mitchell, M. S.: "Social exchange theory: An interdisciplinary review," $J$. Manage., vol. 31, no. 6, pp. 874-900, (2005).

[20] Eckhardt, A.Laumer, S.Maier, C.and Weitzel, T.: "The effect of personality on IT personnel's job-related attitudes: Establishing a dispositional model of turnover intention across IT job types," J. Inf. Technol., vol. 31, no. 1, pp. 48-66, (2016).

[21] Zhang, R.-P. and Tsingan, L.: "Extraversion and neuroticism mediate associations between openness, conscientiousness, and agreeableness and affective well-being," J. Happiness Stud., vol. 15 , no. 6, pp. 1377-1388, (2014)

[22] Brees, J.Martinko, M.and Harvey, P.: "Abusive supervision: subordinate personality or supervisor behavior?,” J. Manag. Psychol., vol. 31, no. 2, (2016).

[23] Lin, Q.-H.Jiang, C.-Q.and Lam, T. H.: "The relationship between occupational stress, burnout, and turnover intention among managerial staff from a Sino-Japanese joint venture in Guangzhou, China," J. Occup. Health, vol. 55, no. 6, pp. 12-287, (2013).

[24] M Almandeel, S.: "The mediating role of transformational leadership style on relationship between personality type and turnover intention in Saudi Arabian banking context," Int. J. Organ. Leadersh., vol. 6, pp. 109-136, (2017).

[25] Tepper, B. J.: "Consequences of abusive supervision," Acad. Manag. J., vol. 43, no. 2, pp. 178190, (2000).

[26] Mitchell, M. S. and Ambrose, M. L.: "Abusive supervision and workplace deviance and the moderating effects of negative reciprocity beliefs.," J. Appl. Psychol., vol. 92, no. 4, p. 1159, (2007).

[27] Alagaraja, M. and Shuck, B.: "Exploring organizational alignment-employee engagement linkages and impact on individual performance: A conceptual model," Hum. Resour. Dev. Rev., vol. 14, no. 1, pp. 17-37, (2015).

[28] Goldberg, L. R.: "An alternative" description of personality": the big-five factor structure.," $J$. Pers. Soc. Psychol., vol. 59, no. 6, p. 1216, (1990).

[29] Haryanto, B.Sarosa, B.Hastjarjo, D.Setyanta, B.and Cahyono, E.: "Can Prostitution in Indonesia be Eliminated?," 2019. 